\title{
A case of Descemet's membrane detachments and tears during phacoemulsification
}

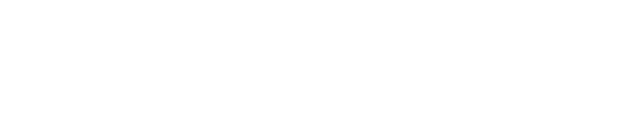

\author{
Yong Wang \\ Huaijin Guan \\ Eye Institute, Affiliated Hospital \\ of Nantong University, Nantong, \\ People's Republic of China
}

\begin{abstract}
Descemet's membrane detachment is an important reason for corneal endothelial decompensation after intraocular surgery. During cataract surgery, it is an unusual complication. We report a case of Descemet's membrane detachment in which approximately $60 \%$ of Descemet's membrane (DM) involving approximately the upper two-thirds of the cornea was torn out during a routine phacoemulsification. It caused diffuse corneal edema and blurred vision in the 2 months following the surgery. Topical prednisolone acetate (1\%) and sodium chloride (5\%) had been used for treatment, with slow improvement in the patient's symptoms and vision. Interestingly, the cornea regained clarity 2 months after surgery without further surgical treatment.
\end{abstract}

Keywords: Descemet's membrane detachment, phacoemulsification, corneal endothelium

\section{Introduction}

Descemet's membrane detachment (DMD) is often attributable to cataract surgery. ${ }^{1-3}$ Various types of DMD can cause corneal endothelial dysfunction. In 1928, DMD was first described by Samuels; ${ }^{4}$ he reported three patients with DMD after iridectomy. Different from the findings of Samuels, ${ }^{4} \mathrm{Scheie}^{5}$ realized the serious surgical complication in his report on three patients who developed DMD after cataract extraction. Since the publication of these initial reports, DMD has also appeared after a wide variety of intraocular surgeries, including iridectomy, ${ }^{6}$ penetrating keratoplasty, ${ }^{7}$ lamellar keratoplasty, ${ }^{8}$ pars plana vitrectomy,${ }^{9}$ and viscocanalostomy. ${ }^{10}$ Few cases of Descemet's membrane (DM) tears were reported, and the cornea regained clarity 2 months after an uncomplicated phacoemulsification without surgical intervention.

To our knowledge, this is the first report of DMD and tears involving approximately the upper two-thirds of the cornea without surgical intervention and the cornea spontaneously regaining clarity.

\section{Case report}

All procedures conformed to the Declaration of Helsinki, and written informed consent was acquired from the participant. The study was approved by the Ethics Committee of Affiliated Hospital of Nantong University. An 83-year-old Chinese man presented with complaints of diminished vision in both eyes, with a best-corrected visual acuity of 20/125 in his right eye and 20/160 in his left eye. Slit-lamp exam (Topcon SL-2D, Japan) of both eyes revealed that he had nuclear type cataract in both eyes (right eye: nuclear opalescence [NO]4, nuclear color [NC]4 and left eye [NO5, NC5]) according to the Lens Opacities Classification System III. ${ }^{11}$ Intraocular pressures were $14 \mathrm{mmHg}$ in both eyes by noncontact tonometer (Canon TX-20, Japan). Cornea was clear and the anterior chamber depth in the left eye was found to be $2.20 \mathrm{~mm}$. Specular endothelial microscopy and cell count showed no significant difference between the two eyes $(2,527$ cells/mm² oculus dexter, 2,420 cells/ $\mathrm{mm}^{2}$ oculus sinister; Topcon-SP3000).
Correspondence: Huaijin Guan Eye Institute, Affiliated Hospital of Nantong University, 20 Xisi

Road, Nantong, Jiangsu 226000,

People's Republic of China

Tel +86 I38 09088972

Fax +86 5I3 85052222

Email guanhjeye@।26.com
Therapeutics and Clinical Risk Management 20I5:I I 1727-1729

1727

Dovepress

http://dx.doi.org// 0.2147/TCRM.S87162 (c) (i) (5) $\odot 215$ Wang and Guan. This work is published by Dove Medical Press Limited, and licensed under Creative Commons Attribution - Non Commercial (unported, v3.0) LY LC Licnse. The full terms of the License are available at http://creativecommons.org/licenses/by-nc/3.0/. Non-commercial uses of the work are permitted without any further permission from Dove Medical Press Limited, provided the work is properly attributed. Permissions beyond the scope of the License are administered by Dove Medical Press Limited. Information on
how to request permission may be found at: http://www.dovepress.com/permissions.php 


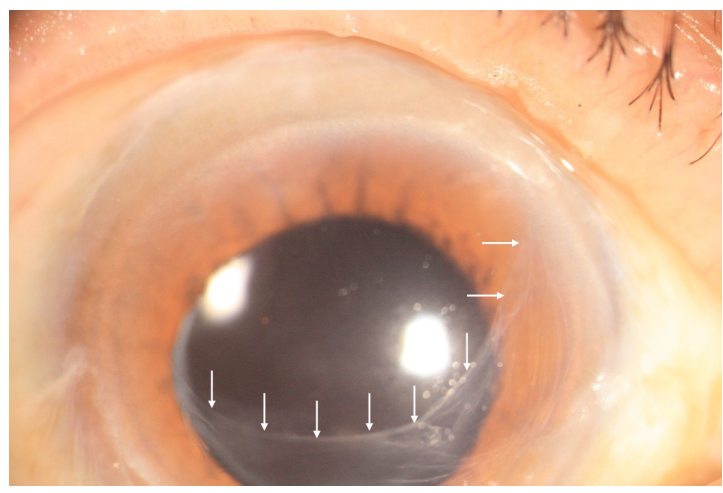

Figure I Slit-lamp color photographs at presentation 2 months after phacoemulsification.

Notes: White arrowheads show the edge of remainder of Descemet's membrane. The cornea regained clarity.

After topical anesthesia, a $3.0 \mathrm{~mm}$ corneoscleral tunnel incision and one side port were made at 11 and 2 o'clock in his left eye. A peristaltic pump-based (LAUREATE ${ }^{\circledR}$, Alcon, INFINITI $^{\circledR}$, USA) phacoemulsification was done. DuoVisc ${ }^{\circledR}$ (Alcon) was used during the procedure. Low ultrasound energy (5\%) was used with an effective phacoemulsification time of 5 seconds. While using the irrigation/aspiration device to remove the lens cortex, we found that the DM was torn, involving approximately the upper two-thirds of the cornea in his left eye. Then a foldable posterior chamber intraocular lens (AcrySof ${ }^{\circledR}$ 1-piece, Alcon, USA) was implanted.

On day 1 after the surgery, the patient came with vision of counting fingers at approximately $10 \mathrm{~cm}$ with diffuse corneal edema in the left eye. The intraocular pressure was $18 \mathrm{mmHg}$. He was started on 1\% prednisolone acetate and 5\% sodium chloride three and six times a day, respectively, for 7 days. Seven days after the surgery, his vision was 20/200 and the remainder of the DM was completely reattached. On the subsequent follow-up, transparency of the cornea was

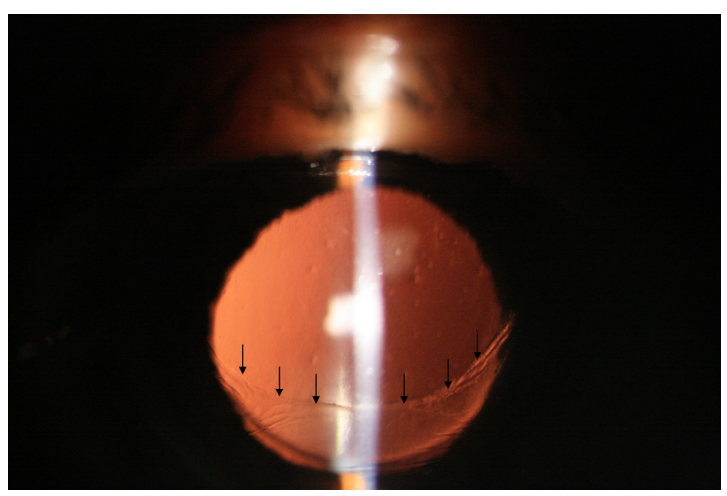

Figure 2 Slit-lamp color photographs at presentation I year after phacoemulsification.

Notes: Black arrowheads show the edge of remainder of scrolled Descemet's membrane. The corneal opacification and scar did not occur. gradually restored. The vision improved to 20/40 2 months after the surgery and the cornea regained clarity without corneal opacification and scar (Figure 1). One year after the surgery, the best-corrected visual acuity in the left eye was 20/50, and the cornea remained clear (Figure 2).

\section{Discussion}

A study reported the incidence of DMD to be $2.6 \%$ for extracapsular cataract extraction and $0.5 \%$ for phacoemulsification. ${ }^{12}$ DMD has also been reported in Descemet membrane endothelial keratoplasty and deep anterior lamellar keratoplasty. ${ }^{13,14}$ Several mechanisms have been implicated in the etiology of DMD, such as a shallow anterior chamber, ${ }^{1}$ use of blunt microkeratomes, ${ }^{15}$ shelved and/ or anteriorly placed incisions, ${ }^{16,17}$ engagement of the DM during intraocular lens implantation, ${ }^{18}$ the inadvertent injection of saline into the space between the deep stroma and the DM. ${ }^{12}$

A study explored the possibility of an underlying anatomic predisposition for the development of DMD, possibly explained by an abnormality in the fibrillary stromal adhesion to DM. ${ }^{2}$ Some patients may have an abnormal attachment between the stroma and DM caused by dysfunction of the anchoring protein $\beta$ ig-h3. ${ }^{8,19}$ We reported the case of DMD and tears during irrigation/aspiration. Many reasons have been attributed to the occurrence of detachments after cataract surgery. However, the scarce literature discusses reasons responsible for DMD when they were torn. Why had this patient developed DM tears during cataract surgery? A logical explanation for this unusual presentation is that the surgeon was inexperienced and using blunt keratomes. During surgery, a tight main incision can not fit the phaco probe. This is the another reason for DMD. The surgeon did not find the DMD before removing the lens cortex until the membrane was torn and removed by irrigation/aspiration device. Interestingly, endothelial dysfunction and bullous keratopathy did not occur in this case. The remainder of corneal endothelium staying viable is the reason the cornea regained clarity. This factor has been attributed to corneal endothelial cell hypertrophy, migration, redistribution, and/or repopulation.

Some similar cases have been reported, but this case report is different. This case of DMD involved approximately two-thirds of the cornea, and recovery without surgical intervention is very rare. There are few manuscripts reporting the detachment and tearing of DM during routine phacoemulsification.

\section{Conclusion}

It is vital to be aware of the potential causes of DMD during cataract surgery, especially when the operation is being 
performed by an inexperienced surgeon. Before initiating a complex surgical procedure such as a keratoplasty for this kind of case, which requires good postoperative care and regular follow-up, proper medication for DM tears is definitely a worthwhile attempt.

\section{Disclosure}

The authors report no conflicts of interest in this work.

\section{References}

1. Stewart CM, Li F, McAlister JC. Late-onset persistent Descemet's membrane detachment following uncomplicated clear corneal incision cataract surgery. Clin Experiment Ophthalmol. 2011;39(2):171-174.

2. Kansal S, Sugar J. Consecutive Descemet membrane detachment after successive phacoemulsification. Cornea. 2001;20(6):670-671.

3. Datar S, Kelkar A, Jain AK, et al. Repeat Descemetopexy after Descemet's membrane detachment following phacoemulsification. Case Rep Ophthalmol. 2014;5(2):203-206.

4. Samuels B. Detachment of Descemet's membrane. Trans Am Ophthalmol Soc. 1928;26:427-437.

5. Scheie HG. Stripping of Descemet's membrane in cataract extraction. Trans Am Ophthalmol Soc. 1964;62:140-152.

6. Mackool RJ, Holtz SJ. Descemet membrane detachment. Arch Ophthalmol. 1977;95(3):459-463.

7. Wigginton SA, Jungschaffer DA, Lee DA. Postoperative Descemet membrane detachment with maintenance of corneal clarity after trabeculectomy. J Glaucoma. 2000;9(2):200-202.

8. Hirano K, Kojima T, Nakamura M, Hotta Y. Triple anterior chamber after full-thickness lamellar keratoplasty for lattice corneal dystrophy. Cornea. 2001;20(5):530-533.
9. Jones MR. Repair of Descemet's membrane detachment with perfluoropropane (C3F8). Cornea. 1998;17(4):457.

10. Unlu K, Aksunger A. Descemet membrane detachment after viscocanalostomy. Am J Ophthalmol. 2000;130(6):833-834.

11. Chylack LT Jr, Wolfe JK, Singer DM, et al. The lens opacities classification system III. The Longitudinal Study of Cataract Study Group. Arch Ophthalmol. 1993;111(6):831-836.

12. Mulhern M, Barry P, Condon P. A case of Descemet's membrane detachment during phacoemulsification surgery. Br JOphthalmol. 1996; 80(2): 185-186.

13. Heindl LM, Riss S, Bachmann BO, Laaser K, Kruse FE, Cursiefen C. Split cornea transplantation for 2 recipients: a new strategy to reduce corneal tissue cost and shortage. Ophthalmology. 2011;118(2):294-301.

14. Venkatraman A. Spontaneous resolution of double anterior chamber with perforation of Descemet's membrane in deep anterior lamellar keratoplasty. Oman J Ophthalmol. 2012;5(2):112-114.

15. Mackool RJ, Holtz JS. Dull knives and Descemet's membrane detachments. Arch Ophthalmol. 1978;96(3):542.

16. Zusman NB, Waring GO 3rd, Najarian LV, Wilson LA. Sulfur hexafluoride gas in the repair of intractable Descemet's membrane detachment. Am J Ophthalmol. 1987;104(6):660-662.

17. John ME, Noblitt RL, Boleyn KL, Raanan MG, DeLuca M. Effect of a superficial and a deep scleral pocket incision on the incidence of hyphema. J Cataract Refract Surg. 1992;18(5):495-499.

18. Makley TA Jr, Keates RH. Detachment of Descemet's membrane with insertion of an intraocular lens. Ophthalmic Surg. 1980;11(8):492-494.

19. Streeten BW, Qi Y, Klintworth GK, Eagle RC Jr, Strauss JA, Bennett K. Immunolocalization of beta ig-h3 protein in 5q31-linked corneal dystrophies and normal corneas. Arch Ophthalmol. 1999;117(1):67-75.
Therapeutics and Clinical Risk Management

\section{Publish your work in this journal}

Therapeutics and Clinical Risk Management is an international, peerreviewed journal of clinical therapeutics and risk management, focusing on concise rapid reporting of clinical studies in all therapeutic areas, outcomes, safety, and programs for the effective, safe, and sustained use of medicines. This journal is indexed on PubMed Central, CAS,

\section{Dovepress}

EMBase, Scopus and the Elsevier Bibliographic databases. The manuscript management system is completely online and includes a very quick and fair peer-review system, which is all easy to use. Visit http://www.dovepress.com/testimonials.php to read real quotes from published authors.

Submit your manuscript here: http://www.dovepress.com/therapeutics-and-clinical-risk-management-journal 